\title{
Amelioration of Lead Toxicity in Pisum sativum (L.) by Foliar Application of Salicylic Acid
}

Ghani A $^{1 *}$, Khan I', Ahmed I', Mustafa I ${ }^{2}$, Abd-Ur-Rehman ${ }^{1}$ and Muhammad $\mathbf{N}^{3}$

${ }^{1}$ Department of Botany, University of Sargodha, Sargodha, Pakistan

${ }^{2}$ Department of Zoology, University of Sargodha, Sargodha, Pakistan

${ }^{3}$ Ayub Agricultural Research Institute, Faisalabad, University of Sargodha, Sargodha, Pakistan

\begin{abstract}
Lead is very toxic heavy metal and commonly found in the polluted soil and water. It harms the plants as well as animals and micro-organisms. Presence of lead in the soil may be the main reason for decrease in the agricultural products. Lead $(\mathrm{Pb})$ is a toxic heavy metal released into the natural environment and known to cause oxidative damage and alter antioxidant mechanism in plants. Lead $(\mathrm{Pb})$ is one of the most important heavy metals frequently available in the environment and its most common sources are vehicles and automobiles. However, not much is known about the interference of $\mathrm{Pb}$ with the biochemical processes and carbohydrate metabolism during seed germination. Lead enters the plants through soil and damages the mechanisms of plants and when animals eat these plants then lead transfer in them and cause major disorders. This study was conducted to find out the compounds with antitoxic properties. An experiment was conducted to reveal the antitoxic effect of Salicylic acid in Pea (Pisum sativum L.). It was noticed that Salicylic Acid showed its action selectively in Pea (Pisum sativum L.) and it was detected that salicylic acid displayed selective action on plant growth parameters in pea. The highest plant height $61.34 \mathrm{~cm}$ was observed after 44 days of the combined application of lead and salicylic acid and lowest value for plant height i.e., $7.15 \mathrm{~cm}$ was observed after 20 days of the combined application of lead and salicylic acid similarly highest numbers of tendrils (29.34) were observed after the 44 days of combined application of lead and salicylic acid. The same trend was observed with respect to number of leaves i.e., 45.78 and 13.56 after 44 and 20 days respectively.
\end{abstract}

Keywords: Pea; Lead toxicity; Salicylic acid; Antibiotics; Disorders

\section{Introduction}

Lead is very toxic environmental pollutant which is widely distributed in the soil and contaminated water. In plants metals enhance the physiological and chemical changes like reduction in growth, yellowing of leaves, decrease in photosynthesis and change in defensive mechanism [1]. Lead is very harmful to human beings [2] and it causes various disorders, effects nervous system, immune system, kidney damage etc. Salicylic acid has potential to regulate the stress response in plants. Salicylic acid has ability to lessen the lead toxicity in plants. The main object of recent study was to investigate the action of lead on plant growth characteristics of Pisum sativum L. and antitoxic effects of salicylic acid. The bioavailable fraction of metal is generally thought to be free metal ion in the soil solution in deficiency and sufficiency situation the free metal ion activity in the soil solution is low and plants have developed strategies to maximize the potential uptake of metals $[3,4]$. Plants are able to influence the solubility and speciation of metals in the rhizosphere by exuding chelators [5] and manipulating rhizospheric $\mathrm{pH}$ [6]. Some chemical transformations can change harmful contaminants into less harmful chemical species, while other processes can produce compounds that are more harmful to ecosystems or human health than the parent compound. The natural decay of some radionuclides can produce daughter products with different transport properties and health effects than the parent product [7]. Plants grown with effluent irrigation tends to accumulate higher amount of metals in their tissues. Large differences in accumulation of heavy metals by cereal and legume crops have been reported [8]. Pisum sativum L. is cultivated on large scale in different parts of the world, including Pakistan which is affected by higher concentrations of toxic metals receive through irrigation water from the water bodies contaminated with industrial effluents. During the last two decades its cultivation has spread widely mainly because of availability superior germplasm development by Asia vegetable Research and Development Centre ( AVRDC), which is better adapted to a wide range of ecological zones.
Although identified as a high yielding crop in many Asian countries, Pisum sativum $L$. is very sensitive to environmental fluctuations and its responses to toxicants such as $\mathrm{Pb}$ need to be explored.

\section{Material and Methods}

The loamy soil land plot was selected for the experiment which was exposed to sunlight openly. Pea seeds were provided by Ayub Agricultural Research Institute Faisalabad (AARI). Complete randomized design was used for the experiment. Four (4) treatments were given to all variants. No treatment for control variants and other variants were treated with lead acetate $\left(\mathrm{Pb}\left(\mathrm{CH}_{3} \mathrm{COO}\right)_{2}-0.25 \mathrm{mg} / \mathrm{L}\right.$, lead+salicylic acid $\left(\mathrm{C}_{6} \mathrm{H}_{4}(\mathrm{OH}) \mathrm{COOH}\right) 10(-4) \mathrm{M}$ and salicylic acid alone respectively. Same irrigation conditions were applied to all these plants. During 4 to 5 weeks, different parameters like plant height, numbers of leaves, number of tendrils, leaf length and leaf width were examined. 50 plants of each variant were examined. Experimental data was shown as mean and standard error.

\section{Effect of lead on plant height}

Table data showed that lead treatment stimulate the plants height It results for the plants which were treated with lead alone (Table 1). Salicylic acid also stimulates plant height but initially there were no changes between the control and salicylic acid treated plants. There

*Corresponding author: Ghani A, Department of Botany, University of Sargodha Sargodha, Pakistan, Tel: 9248 9230811; E-mail: Ghaniuaf8@gmail.com

Received February 02, 2015; Accepted April 25, 2015; Published April 30, 2015

Citation: Ghani A, Khan I, Ahmed I, Mustafa I, Abd-Ur-Rehman, et al. (2015) Amelioration of Lead Toxicity in Pisum sativum (L.) by Foliar Application of Salicylic Acid. J Environ Anal Toxicol 5: 292. doi:10.4172/2161-0525.1000292

Copyright: @ 2015 Ghani A, et al. This is an open-access article distributed under the terms of the Creative Commons Attribution License, which permits unrestricted use, distribution, and reproduction in any medium, provided the original author and source are credited. 
Citation: Ghani A, Khan I, Ahmed I, Mustafa I, Abd-Ur-Rehman, et al. (2015) Amelioration of Lead Toxicity in Pisum sativum (L.) by Foliar Application of Salicylic Acid. J Environ Anal Toxicol 5: 292. doi:10.4172/2161-0525.1000292

Page 2 of 3

\begin{tabular}{|c|c|c|c|c|c|}
\hline Parameter & Day of observation & Control & Lead & SA & Lead+SA \\
\hline \multirow[t]{5}{*}{ Plant height, cm } & 20 & $5.01 \pm 0.37$ & $6.85 \pm 0.45$ & $4.85 \pm 0.41$ & $7.15 \pm 0.27$ \\
\hline & 26 & $11.54 \pm 0.69$ & $14.5 \pm 0.86$ & $12.96 \pm 0.78$ & $15.25 \pm 0.76$ \\
\hline & 32 & $16.21 \pm 0.89$ & $26.31 \pm 1.13$ & $22.50 \pm 1.03$ & $21.55 \pm 1.31$ \\
\hline & 38 & $29.03 \pm 1.64$ & $39.46 \pm 1.06$ & $39.52 \pm 1.35$ & $38.62 \pm 1.2$ \\
\hline & 44 & $45.26 \pm 2.29$ & $46.32 \pm 0.65$ & $63.42 \pm 1.24$ & $61.34 \pm 1.5$ \\
\hline \multirow[t]{5}{*}{ Number of tendrils } & 20 & $1.43 \pm 0.18$ & $2.13 \pm 0.15$ & $3.55 \pm 0.18$ & $2.41 \pm 0.3$ \\
\hline & 26 & $3.97 \pm 0.27$ & $4.23 \pm 0.28$ & $4.02 \pm 0.21$ & $4.98 \pm 0.26$ \\
\hline & 32 & $7.13 \pm 0.40$ & $8.07 \pm 0.51$ & $8.13 \pm 0.44$ & $7.89 \pm 0.56$ \\
\hline & 38 & $16.74 \pm 0.98$ & $18.22 \pm 0.59$ & $19.34 \pm 1.51$ & $18.1 \pm 0.6$ \\
\hline & 44 & $34.12 \pm 1.89$ & $29.42 \pm 0.76$ & $30.46 \pm 1.12$ & $29.34 \pm 1.1$ \\
\hline \multirow[t]{5}{*}{ Number of leaves } & 20 & $2.64 \pm 0.29$ & $8.44 \pm 0.58$ & $11.21 \pm 0.56$ & $13.56 \pm 0.57$ \\
\hline & 26 & $7.83 \pm 0.46$ & $22.51 \pm 0.54$ & $20.12 \pm 0.62$ & $17.82 \pm 0.64$ \\
\hline & 33 & $13.21 \pm 0.57$ & $27.36 \pm 0.61$ & $25.49 \pm 0.71$ & $24.95 \pm 0.4$ \\
\hline & 38 & $27.41 \pm 1.31$ & $34.58 \pm 0.96$ & $39.52 \pm 1.13$ & $35.67 \pm 1.63$ \\
\hline & 44 & $43.37 \pm 2.32$ & $56.93 \pm 0.74$ & $51.26 \pm 1.17$ & $45.78 \pm 1.57$ \\
\hline \multirow[t]{5}{*}{ Leaf length, $\mathrm{cm}$} & 20 & $2.61 \pm 0.2$ & $1.56 \pm 0.09$ & $2.11 \pm 0.12$ & $2.03 \pm 0.23$ \\
\hline & 26 & $3.82 \pm 0.1$ & $2.73 \pm 0.05$ & $2.91 \pm 0.13$ & $3.71 \pm 0.1$ \\
\hline & 32 & $2.57 \pm 0.08$ & $3.65 \pm 0.04$ & $4.02 \pm 0.16$ & $3.89 \pm 0.09$ \\
\hline & 38 & $4.07 \pm 0.17$ & $4.54 \pm 0.12$ & $3.98 \pm 0.15$ & $4.65 \pm 0.1$ \\
\hline & 44 & $5.12 \pm 0.21$ & $4.95 \pm 0.04$ & $6.54 \pm 0.18$ & $5.34 \pm 0.14$ \\
\hline \multirow[t]{5}{*}{ Leaf width, $\mathrm{cm}$} & 20 & $2.14 \pm 0.13$ & $1.23 \pm 0.06$ & $2.13 \pm 0.21$ & $2.01 \pm 0.23$ \\
\hline & 26 & $1.67 \pm 0.08$ & $2.61 \pm 0.05$ & $3.10 \pm 0.16$ & $1.76 \pm 0.12$ \\
\hline & 32 & $3.11 \pm 0.07$ & $3.16 \pm 0.04$ & $2.85 \pm 0.14$ & $3.02 \pm 0.16$ \\
\hline & 38 & $3.94 \pm 0.14$ & $4.07 \pm 0.01$ & $2.99 \pm 0.06$ & $2.94 \pm 0.15$ \\
\hline & 44 & $4.13 \pm 0.19$ & $4.75 \pm 0.03$ & $4.23 \pm 0.15$ & $4.12 \pm 0.1$ \\
\hline
\end{tabular}

Table 1: Effects of lead and salicylic acid on plant growth parameters.

were similar result in case of lead and salicylic acid treated plants. A little amount of lead may stimulate the production of gibberellic acid with growth stimulating effects [9] and also inhibit the plant height. For cadmium and Vigna plants similar results were obtained [10].

\section{Effect of lead on number of tendrils}

In all these variants (lead alone, salicylic acid alone and their combination), there were no phenotypic changes were detected. Insufficient amount of lead and salicylic acid cause no changes in the number of tendrils [11].

\section{Effect of lead on number of leaves}

Number of leaves increased in the experimental variants. Lead and salicylic acid alone treated variants did not show more difference till the end of observation. These variants showed their reaction in response to heavy metal [12] by increasing the number of leaves. It was considered adaptive reaction of plants to metal stress [13-23].

\section{Effect of lead on leaf length and leaf width}

In our experiment, we did not find statistical changes in leaf length and leaf width. These changes were not shown in the variants which were treated with lead, lead+salicylic acid and salicylic acid alone.

\section{Conclusion}

In this study the toxic effects of lead on the plant growth, plant height and number of leaves were observed. Strategic changes occurred in various attributes in response to lead stress. To observe the beneficiary effect of salicylic acid to ameliorate the lead toxicity a wide range of concentrations of salicylic acid is needed to be utilized. From this study it can be concluded that the growth attributes increased significantly with the increasing number of days after the combined application of lead and salicylic acid and salicylic acid ameliorated the toxic effects of lead up to great extent i.e the lowest plant height $6.85 \mathrm{~cm}$ was observed in the presence of lead while highest value for the plant height $(63.42$ $\mathrm{cm}$ ) was noticed after the application of salicylic acid. Similar trend was observed with respect to other growth attributes.

\section{References}

1. Hall JL (2002) Cellular mechanisms for heavy metal detoxification and tolerance. J Exp Bot 53: 1-11.

2. Moyo DZ, Chimbira C (2009) The effect of single and mixed treatments of lead and cadmium on soil bioavailability, uptake and yield of Lactuca sativa irrigated with sewage effluent under greenhouse conditions. American-Eurasian Journal of Agricultural and Environmental Sciences 6: 526-531.

3. Welch RM, Shuman L (1995) Micronutrients nutrition of plants. Plant sciences 14: 49-82.

4. Wojcik M, Vangronsveld J, Tukiendorf A (2005) Cadmium tolerance in Thlaspi caerulescens. II. Localization of cadmium in Thlaspi caerulescens. Environmental Experimental Botany 53: 151-161.

5. Fan TW, Lane AN, Pedler J, Crowley D, Higashi RM (1997) Comprehensive analysis of organic ligands in whole root exudates using nuclear magnetic resonance and gas chromatography-mass spectrometry. Anal Biochem 251 57-68. 
Citation: Ghani A, Khan I, Ahmed I, Mustafa I, Abd-Ur-Rehman, et al. (2015) Amelioration of Lead Toxicity in Pisum sativum (L.) by Foliar Application of Salicylic Acid. J Environ Anal Toxicol 5: 292. doi:10.4172/2161-0525.1000292

6. Peralta-Videa JR, Gardea-Toressdey E, Gomez E, Tiemann KJ, Parson JG, Carrillo G (2002) Effects of mixed cadmium, copper nickel and zinc at different $\mathrm{pH}$ upon Alfalfa growth and heavy metal uptake. Environmental Pollution 119 291-301.

7. Focazio MJ, Szabo Z, Kraemer TF, Mullin AH, Barringer TH, et al. (2000) Occurrence of selected radionuclides in ground water used for drinking water in the United States: A reconnaissance survey, 1998. U.S. Geological Survey Water-Resources Investigations Report 00-4273.

8. Kumar PBAN, Dushenkov V, Motto H, Raskin I (1995) Phytoextraction: The use of plants to remove heavy metals from soils. Environ Sci Technol 29: 12321238.

9. Mohamed Mansour M, Abdel-Razik Kamel E (2005) Interactive effect of heavy metals and gibberellic acid on mitotic activity and some metabolic changes of Vicia faba L. plants. Cytologia 70: 275-282.

10. Sabnis DD, Gordon M, Galston AW (1969) A site with an affinity for heavy metals on the thylakoid membranes of chloroplasts. Plant Physiol 44: 13551363.

11. Azmat R, Haider S, Nasreen H, Aziz F, Riaz M (2009) A viable alternative mechanism in adapting the plants to heavy metal environment. Pakistan Journal of Botany 41: 2729-2738.

12. Enyedi AJ, Yalpani N, Silverman P, Raskin I (1992) Signal molecules in systemic plant resistance to pathogens and pests. Cell 70: 879-886.

13. Aderinola OJ, Clarke EO, Olarinmoye OM, Kusemiju V, Anatekhai MA (2009) Heavy Metals in Surface Water, Sediments, Fish and Perwinkles of Lagos Lagoon. American-Eurasian J Agric \& Environ Sci 150: 609-617.
14. Callan AC, Hinwood AL (2011) Exposures to lead. Reviews on Environmental Health 26:13-15

15. Ding CK, Wang CY, Gross KC, Smith DL (2002) Jasmonate and salicylate induce expression of pathogenesis-related protein genes and increase resistance to chilling injury in tomato fruit. Planta 214: 895-901.

16. Fergusson JE (1991) The heavy elements: chemistry, environmental impact and health effects. 614

17. Florijn PJ, Van Beusichem ML (1993) Uptake and distribution of cadmium in maize inbred lines 150: 25-32.

18. Foy CD, Chaney RL, White MC (1978) The physiology of metal toxicity in plants. Annual Reviews 29: 511-566

19. Jothinayagi N, Anbazhagan C (2009) Heavy metal monitoring of Rameswaram coast by some Sargassum species. American-Eurasian Journal of Scientific Research 4: 73-80.

20. Khan S, Farooq R, Shahbaz S, Khan MA, Sadique M (2009) Health risk assessment of heavy metals for population via consumption of vegetables. World Applied Sciences Journal 6: 1602-1606.

21. Metwally A, Finkemeier I, Georgi M, Dietz KJ (2003) Salicylic acid alleviates the cadmium toxicity in barley seedlings. Plant Physiol 132: 272-281.

22. Mangkoedihardjo S, Surahmaida (2008) Jatropha curcas L. for phytoremediation of lead and cadmium polluted soil. World Applied Sciences Journal 4: 519-522.

23. Sharma P, Dubey RS (2005) Lead toxicity in plants. Braz J Plant Physiol 17 $35-52$. 